\title{
San Benedetto teaching two monks
}

\author{
E. Martino ${ }^{1}$
}

Received: 28 March 2017 / Accepted: 29 March 2017 / Published online: 21 June 2017

(C) Italian Society of Endocrinology (SIE) 2017

Giovanni Antonio Bazzi known as Sodoma was a painter born in Vercelli (Piedmont-Northern Italy) in 1477 and died in Siena 1549. He was active mainly in Tuscany and he was famous for their frescos.

In the main cloister of Monte Oliveto Maggiore Abbey, near Siena-Tuscany, he made a large frescos representing Saint Benedetto's life; in particular, this fresco represents the Saint teaching to two monks how build the Abbey. One of them has a large nodular goiter, which was very common in Europe and also in Italy. This characteristic is also depicted by Sodoma in other scenes in the same abbey [1] and by other artists of the same period in different Italian countries and churches [2-4].

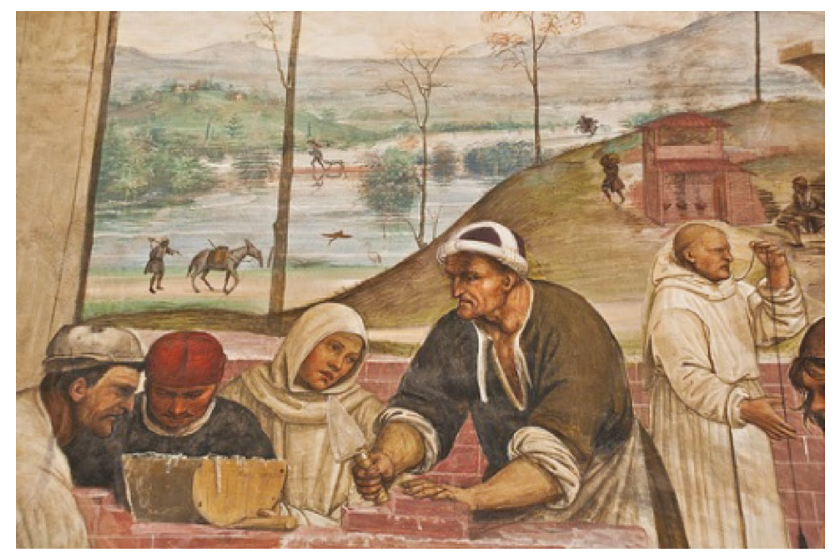

Giovanni Antonio Bazzi detto il Sodoma (1477-1549) Come Benedetto appare a due monaci lontani e loro disegna la costruzione di uno monastero (particolare)

Abbazia di Monte Oliveto Maggiore - Asciano - Siena (Italia)

E. Martino

enio.martino@gmail.com

1 University of Pisa, Pisa, Italy

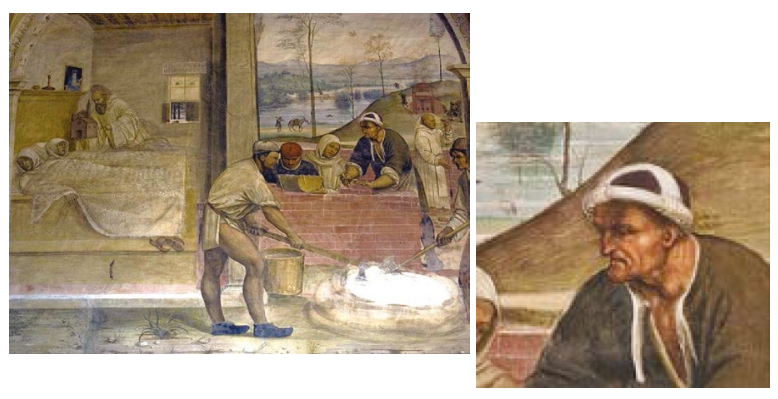

Giovanni Antonio Bazzi detto il Sodoma (1477-1549) Come Benedetto appare a due monaci lontani e loro disegna la costruzione di uno monastero Abbazia di Monte Oliveto Maggiore - Asciano - Siena (Italia)

\section{Compliance with ethical standards}

Conflict of interest The authors declare that they have no conflict of interest.

Ethical approval This paper does not contain any studies with human participants or animals performed by any of the authors.

Informed consent No informed consent.

\section{References}

1. Gheri R (1999) San Benedetto teaching the Christian faith to the peasants. JEI 22:408

2. Lazzeri D et al (2015) Nativity-renaissance portal in the Aosta Cathedral. JEI 38:113-114

3. Barale $M$ et al (2015) The martyrdom of Saint Sebastian. JEI 38:375

4. Barale M (2015) Man with enormous trilobar goiter. JEI 38:575 